\title{
The transcriptions of the Three Teachers: an old or a new sound? ${ }^{1}$
}

IOANNIS V. ARVANITIS ${ }^{\star}$

^Professor of Byzantine Music. - arvanitisps@yahoo.com.

200 years ago, the Ecumenical Patriarchate called a synod, to honour the Three Teachers, that is the three reformers of the notational system of Eastern Orthodoxy's ecclesiastical chant tradition: Chrysanthos of Madytos, Archimandrite and subsequently Archbishop of Dyrrachium (modern day Durrës, Albania), Gregorios the Lampadarios and then Protopsaltis of the Great Church, and Chourmouzios, a music teacher, then honoured with the officium of Archivist. The synod gave an official status to their so-called New Method (hereafter abbreviated as NM) and issued an encyclical inviting all cantors to Constantinople to learn this method. 200 years later, the music-loving mood of this journal's publishers brought us as well, to honour these men. Although mentalities and psaltic habits might have changed, we understand ourselves descendants from these three men whom we see as benefactors, and therefore we also feel the duty to honour them.

\section{Exegetical selectivity of the Three Teachers}

The Three Teachers (hereafter abbreviated as 3T) presented and taught the NM as a theoretical and practical tool; however they also proceeded to transcribe the byzantine and post-byzantine repertory into NM notation. ${ }^{2}$ This massive body of the so-called "exegeseis" offers us transcriptions of older music settings, originally written in older phases of the notation, into their own method and notation. It would be of some importance to note exactly what they transcribed, but I will not attempt it here. I will only note that although it is true that they transcribed a large part of the old Byzantine Music repertory, there seem to be various "gaps" in their attempt, as well.

For example, the old heirmologia, those before the one by Peter the Peloponnesian $\left(2^{\text {nd }}\right.$ half of the $18^{\text {th }} \mathrm{c}$ ), have not, with the exception of only a few chants, been transcribed. In other words, the older heirmologia by Balasios $\left(17^{\text {th }} \mathrm{c}\right)$, Karykis $\left(16^{\text {th }} \mathrm{c}\right)$, Koukuzelis $\left(14^{\text {th }} \mathrm{c}\right)$, or the even older ones, of the $13^{\text {th }}$ and $12^{\text {th }}$ c, have never been transcribed. And, while the Old Sticherarion of the Byzantine period has been transcribed, some of the Sticheraria belonging to the "transitional" $15^{\text {th }}$ and $16^{\text {th }} \mathrm{cc}$., have not; and due to this gap, we jump directly to the seventeenth-century Sticheraria of Panagiotis the new Chrysaphis and of Germanos of Neopatras (New Patras).

Concerning the papadic chants, we could say there is a smaller historical gap, in the sense that a great many chants of the Old Papadike were transcribed. These, however, were mainly those still pertaining to common ecclesiastic practice or of some didactic value during the last 1-2 centuries before the 3T. In our day, in the contemporary curricula for ecclesiastic music schools, in our day, it is compulsory to teach chants that might never be of much practical importance during a real church service. This seems also to have been the case back then. Moreover, the repertory that was codified and survived up to the $19^{\text {th }} \mathrm{c}$. was mostly transmitted in some bulky, "monumental" Papadike codices compiled for the first time in the first half of the $18^{\text {th }} \mathrm{c}$. They contain a large number of chants, taken from the totality of papadic melopoiia of all previous

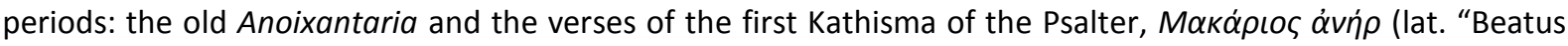
vir"), by the various melodists of the Byzantine period, the Prokeimena ("Dochai"), the old Polyeleoi, Latrinos and Koukoumas, kalophonic verses, pre-Fall period Cherubic and Communion hymns composed prior to 1453, but also post-conquest mele by melodists such as Konstantinos of Anchialus, Karykis, Panagiotes the New

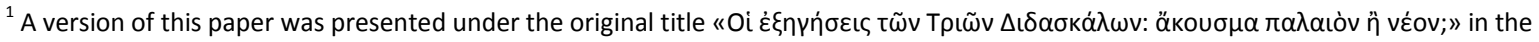
International Musicological Conference "1814-2014: 200 years since the Musical Reform" at Megaron Athens Concert Hall (October 17, 2014), organized by the Scholeion Psaltikes Music School. Revised text here published under the author's kind licence. English translation and editing of the initial transcript draft by Demetra-Maria and Georgios V. Savvas; final additions by the author.

${ }^{2}$ It is mainly Gregorios and Chourmouzios those who undertook the task of the exegeseis, i.e. transcriptions. Nevertheless, I will refer to them collectively as "Three Teachers".
} 
Chrysaphes, Germanos, Balasios, Bereketis $\left(17^{\text {th }}\right.$ c. $)$, etc. ${ }^{3}$ As far as the repertory, the order of appearance of the chants and their exact musical form is concerned, it is these bulky Papadikai that the transcriptions of the 3T connect to and accurately match, and not the older Mss of the $14^{\text {th }}$ or $15^{\text {th }} \mathrm{cc}^{4}$ So, the only really old Ms used for the transcriptions of the $3 \mathrm{~T}$ was the Old Sticherarion. The remaining chants were transcribed from later sources of the $18^{\text {th }} \mathrm{c}^{5}$

These papadic mele cover most periods of grecophone Eastern Orthodox ecclesiastical chant from the era of Koukouzelis onward. The 3T, however, appear not to have made an effort to transcribe the middle

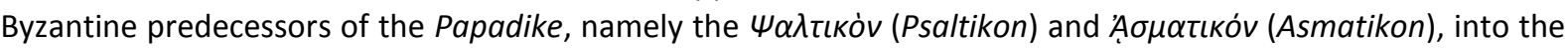
NM notation. Perhaps the 3T never had direct access to these collections, being acquainted only with the few mele from the Psaltikon and the Asmatikon that survived in modified forms in the Papadic anthologies.

The $3 \mathrm{~T}$ naturally also transcribed mele by the later teachers and melodists of the Ecumenical Patriarchate of Constantinople, such as Ioannis of Trebizond, Daniel the Protopsaltes, Petros the Lampadarios et al. $\left(18^{\text {th }} \mathrm{c}\right)$, which were also in use as much in teaching, as in the daily church practice.

This is essentially the repertory transcribed by the $3 T$ in the NM. Their selectivity regarding what to transcribe and what to omit deserves further study, but need not detain us here.

More significant for us is that they portrayed the older musical notation in the transcriptions as stenographic. The old sticheraric and papadic chants, as well as the very few old heirmologic ones, were transcribed in the so-called "long exegesis", where a single phonetic sign on one syllable often received a multinote transcription of a total duration of 8 beats. The primary exceptions are some heirmologic and papadic compositions from the $17^{\text {th }}$ c. on, like the Doxologiai, which they transcribed in a shorter manner, with 2 beats for most simple signs.

\section{Defenders and Opponents of the New Method}

The novelty of the NM naturally gained both defenders and opponents in its time: both acceptance and backlash. The reactions regarded the integrity and maintenance of the interpretative and cantoring practical performance. There was some doubt as to the success that the NM had in capturing the ecclesiastical chant's execution, including, for example, the full detail of its ornamentation. ${ }^{6}$ What seems to not have been questioned, however, was whether the 3T's exegeseis fairly represented the old Byzantine sound. In other words, no doubts were expressed regarding the validity of long exegesis as a tool to represent the old style as originally sung and heard. Instead, it was generally accepted that the transcriptions of the 3T accurately documented the shape of melodies as they were chanted during the Middle Ages, for example in the temple of Hagia Sophia ca. 1200. This position was only challenged later, and herein lies the focus of the present study.

The issue was firstly raised from inside the Ecumenical Patriarchate during the time of Patriarch loakeim III, and in particular by the patriarchal secretary, Markos Vassileiou, a friend and co-chanter of the patriarchal Protopsaltes lakovos Naupliotis. Vassileiou published a series of articles in Ecclesiastic Truth, the official organ of the Patriarchate, in which he argued that the exegeseis received from the 3T do not accurately represent the original sound of at least the older mele, namely those from such melodists as Koukouzelis,

\footnotetext{
${ }^{3}$ These Papadikai usually reach till Balasios, the youngest of the composers of the $17^{\text {th }} \mathrm{c}$. Sometimes, some compositions of other lesser composers, not belonging to the "codified" repertory, may be included. Bereketis is not usually included because another type of manuscript, his "Apanta" (Opera omnia) is especially dedicated to him.

${ }^{4}$ One needs only to compare the transcriptions into the NM by Chourmouzios, found in various volumes of the Metochion Panagiou Taphou collection, to these Papadikai, to ascertain the truth of this statement. The same holds true for transcriptions of Gregorios in the pre-NM "exegetic" notation in Folder 6, notebook 140 of his Archive (kept in K. Psachos library). On the other hand, a comparison of the exegesis of a certain chant to its record in a Ms of the $14^{\text {th }}$ or $15^{\text {th }} \mathrm{c}$ may show that they do not always match.

${ }^{5}$ The $3 T$ also transcribed the Mathimatarion, Kratematarion and Oikematation, which are collections exclusively devoted to kalophonic chants. For these, too, they seem to have transcribed a more or less codified repertory from later sources. Discrepancies between the transcription of a certain Kratema from its version in the Ms NLG $2406\left(15^{\text {th }} \mathrm{c}\right.$ ) led me first to notice the facts I am describing here.

${ }^{6}$ I will not deal with this here. Let us currently consider for the purposes of this article, that the $3 T$ have accurately rendered back what was chanted in Church, as to the small ornaments or the performance of the signs, etc.
} 
Panaretos, Manouel Chrysaphes, and Koronis. ${ }^{7}$ These composers, according to Vassileiou, did not employ notation in a stenographic manner. Accordingly, he transcribes a simple sign placed over a single syllable in their chants as a 1-beat note. Vassileiou viewed the exegeseis provided by the 3T as the result of the subsequent developments and interpretations that formed the chant aesthetics of the 3T's era. This approach may be seen, for example, in his very short rendering of the so-called "ancient melos" (in actual fact, of the $17^{\text {th }}$ c.) of $\Phi \tilde{\omega} \varsigma$ I $1 \lambda \alpha \rho o ́ v$ (Phos Hilaron, lat. Lumen Hilare): ${ }^{8}$

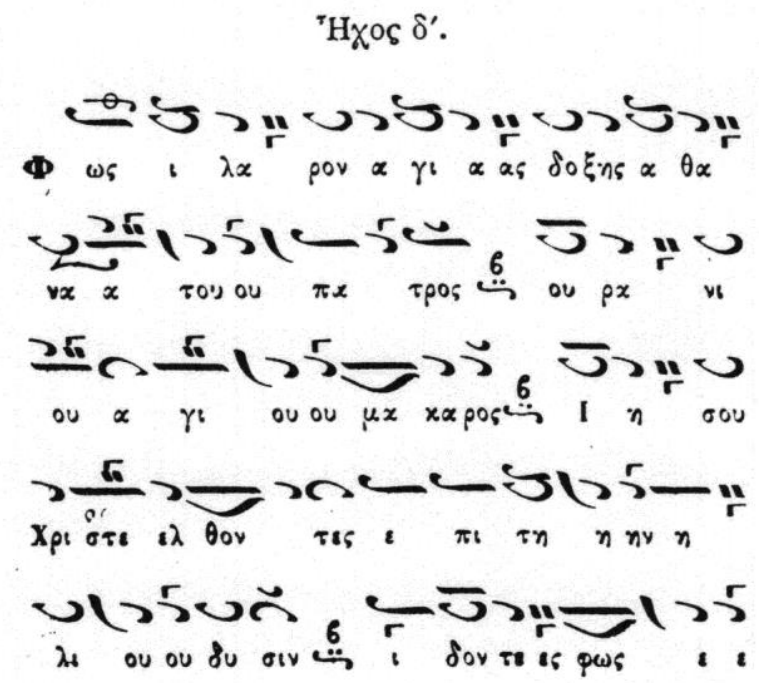

Vassileiou also published some short exegeseis in the magazine Music (Mouorkń) without fully describing how and why he came to this conclusion and why he transcribed thus, without exposing the details for this transcriptional interpretation. He published some stichera and heirmoi, as well as a few papadic and kalophonic chants. In my opinion, he overreaches by assuming, that not only these old chants, but also some later chants must have originally been shorter normally, e.g. the doxology in the first mode by loannis of Trebizond $\left(18^{\text {th }} \mathrm{c}\right)$, for which he also gives an example of his short exegesis. ${ }^{9}$ He uses, mistakenly, the term "metrophonia" for his interpretation.

Beginning in the $20^{\text {th }}$ c., various Western musicologists took note of these questions. These researchers and scholars, primarily those who contributed to the Monumenta Musicae Byzantinae (MMB) series of manuscripts from the Byzantine period, started examining early Byzantine music manuscripts, and subsequently argued that the "old" melodies ${ }^{10}$ must have originally been shorter in duration. These researchers argued that, during the Byzantine period, the notation could not have been stenographic, even if it appeared to be so later. Accordingly, they attempted their own interpretation and transcription of particular mele. ${ }^{11}$

On the Greek side again, Constantinos Psachos opposed the position of M. Vassileiou and of the western scholars by reasserting the stenographic understanding of medieval chant notation. Seemingly supported in this position by Georgios Violakis, ${ }^{12}$ Psachos maintained that the $3 T^{\prime}$ 's exegeseis capture without change the sound of chant in Byzantium, bringing to life the aural world of Hagia Sophia in its heyday.

\footnotetext{
${ }^{7}$ For the work of M. Vassileiou, see Markos Dragoumis's article: Markos Vasileiou, a Pioneer of Byzantine Musicology, in Hannick (ed), Rhythm in Byzantine Chant. Acta of the congress held at Hernen Castle in November 1986, A. A. Bredius Foundation, Hernen, 1991, pp. 45-53. A list of M. Vassileious's publications is also included there.

${ }^{8}$ The 3T, following the previous exegesis by Petros Lampadarios, transcribed this chant with 4 beats per syllable. On the transmission of this melody, see the forthcoming study by Eustathios Makris, 'The Concept of "Old Melody" in Modern Greek Chant: Two Characteristic Cases', to be published in Christian Troelsgård and Gerda Wolfram, eds., Byzantine Chant, Radiation and Interaction: Proceedings of the Congress Held at Hernen Castle, the Netherlands, in December 2015 (Peeters: Leuven).

${ }^{9}$ The $3 \mathrm{~T}$ have transcribed this Doxology with 2 beats for a simple sign.

${ }^{10}$ Namely those notated by composers during the imperial Byzantine period predating $17^{\text {th }}$ or $18^{\text {th }} \mathrm{cc}$. manuscripts. These manuscripts were the principal interest of the MMB editorial board.

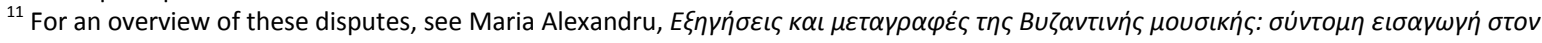

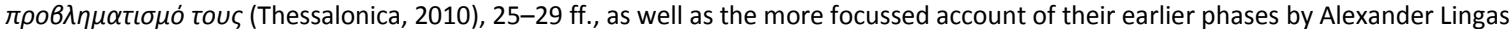
'Performance Practice and the Politics of Transcribing Byzantine Chant,' Acta Musicae Byzantinae 6 (2003), 56-76.

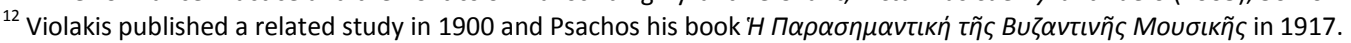


Later in the twentieth century my teacher, Simon Karas, provoked another dispute over the interpretations and transcriptions of the $3 \mathrm{~T}$. He proposed that a shorter exegesis was possible for the older phases of the chant notation, but unlike Vassileiou, did not go as far as to suggest a strictly syllabic schema. ${ }^{13}$ Instead of a one-to-one ratio of beats per neume (e.g., a petaste), Karas suggested an average duration of two beats per neume with the addition of some small ornamentation. Notation was, according to him, "minimally stenographic" and not "fully stenographic". In some respects, however, Karas overreached in his application of this theory, going so far as to transcribe the entire late eighteenth-century Doxastarion of lakovos Protopsaltis according to his proposed short manner. ${ }^{14}$

Such is a brief overview of various scholars' assessments of whether the exegeseis by the 3T correctly render the original soundscape of the old compositions. Let us be clear that none of the researchers discussed above, save for Vassileiou and only him to a limited extent, questioned whether or not the 3T's work represented a faithful transmission of the Heirmologion, the Doxastarion by Petros Lampadarios, or Daniel Protopsaltis' compositions etc. The dispute arose concerning solely manuscripts from the 17 th c. and earlier.

\section{On short exegesis: personal contribution \& examples.}

When I began my own research of the musical mss back in 1982, my point of departure was naturally the 3T's exegeseis and their almost indisputable status as the link to the past. I say "almost," because Simon Karas' views raised further questions in my own mind. Gradually I acquainted myself with the exegeseis of the 3T through thorough study and attempted to discover their mechanisms of transcribing the theseis (formulas) in other words, I tried to find the "key" to their exegeseis. I sought not only a "dictionary" containing the "right" exegesis for this or that thesis; what I needed more was a "primer" for the underlying logic and "grammar." And truly, with God's help, since 1983-84, I have begun to detect the underlying mechanism of the "how" and "why" the 3T transcribed the old notation to the NM. I will not elaborate more here on the details of the process, but the crux of the matter is that these studies of mine on the 3T's work also led me to doubt that their exegeseis accurately mirrored the original sound of the old chants. In an attempt to sum up the questions that have spurred me on to find solutions - and I believe that I have found solutions to many of them - I will offer a classification of the various issues. There are interpretational and performative research questions regarding the notation that pertain to both the musicological and philological fields:

A first issue is whether the notation was interpreted in earlier music the way that the 3T interpreted it. Let us call it a "musicological" issue. There is also the issue of a chant evolving and changing during the centuries. A simple juxtaposition of the $14^{\text {th }} \mathrm{C}$. Papadikai with the aforementioned $18^{\text {th }} \mathrm{C}$. ones (from which the 3T transcribed) will suffice to attest to the differences there; the lack of full identity between the same melos in each of the mss is apparent. Depending on the specific instance, these differences might simply be variations, or they may raise more involved issues of notation and exegesis.

For instance, a melos attributed by name to Koukuzelis in a later period Papadike does not necessarily guarantee verbatim transmission from its time until Chourmouzios' era. The expected variations from Koukuzelis' day and later are one thing, and probably their interpretation would be close to what the composer himself would express. However, variations from manuscripts centuries later often appear to indicate a change in the interpretation of notation. I suggest this as a topic for further research by those keen on clarifying such "philological" issues, as they could be called; they are certainly matters of no minor importance (and the "philological" issues could shed helpful light on the "musicological" issues, as they are to a certain degree connected).

Beyond issues of the exegesis of neumes and of theseis (formulas), another category of question concerns the kind of the musical intervals and their sizes. Specifically, the intervals of the authentic and plagal Second modes are central to these questions. During my study of the mss, the evidence led me to conclude

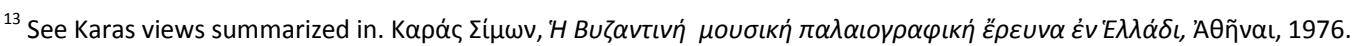

${ }^{14}$ This was transcribed with a long exegesis by Chourmouzios. In an (unpublished) paper of mine of 2015, I showed, through "internal evidence", that this was actually the correct way of interpreting it.
} 
that the Second modes were once most likely not chromatic, as is now widely believed, but rather diatonic, and their "chromatisation" is a subsequent evolution through various stages.

To elaborate: it is certain that there are mele we chant differently today from the way they were chanted through at least the fifteenth century, examples of which include the Apolytikia, the Kathismata, and the Kontakia of the fourth mode. These melodies in the papadic anthologies clearly appear to be diatonic. ${ }^{15}$ Nevertheless, the fourth mode's apolytikia and kathismata transcribed by the 3T as they appear in such anthologies as the Anastasimatarion, or from Chourmouzios' transcriptions found in ms Metochiou Taphou 704, clearly bear chromatic phthorai. However, these belong to the tradition of the $17^{\text {th }} \mathrm{c}$., and it is beyond doubt that they have a different melodic shape from that shown in the older tradition. It is thus certainly the case that at one point, chanters sang something diatonic, and we now chant something chromatic instead. This question of the intervals of the second modes and their evolution concerns chants and theseis that are the same or almost the same from the older tradition until today - e.g., a Communion chant or a sticheron in the authentic or plagal second mode could have originally been diatonic, but it seems to have changed in the chain of transmission, reaching us today as chromatic. In pursuing this question, I have collected evidence for a diatonic original form of these modes. ${ }^{16}$ I present here, of course, my own interpretation, but it is grounded as thoroughly as possible in the evidence of the mss.

The conclusions of my study on the stenographic character of the notation would rather favour simplicity. Based on my observations from the mss, I propose that the notation was primarily to be read in a simple, non-stenographic manner. In my PhD thesis (2010), ${ }^{17}$ I give in detail, at least for stichera and heirmoi, the specific rules concerning the duration and the exact interpretation of the signs and their combinations.

To my reading, this state of affairs holds until at least the $14^{\text {th }}-15^{\text {th }}$ cc. A new stage then begins in which cantors gradually double the durations of the notes, and consequently of the musical signs, simultaneously adding ornaments. Eventually this longer, slower form of the melos is additionally enriched, and as the notation at this point enters the stenographic realm, every single neume or syllable is expanded to eight beats of duration. The level of time expansion eventually notated in the 3T's transcriptions increases sometimes up to as many as sixteen beats - a significant lengthening from the initial mele.

As mentioned above, there is ample evidence that there once was a short exegesis. A good case study that makes this clear is the similarity of the theseis in the Old Heirmologion to those of the Old Sticherarion; in fact, their lines in the various old mss are identical. Of particular interest is that the Sticherarion was delivered by the $3 \mathrm{~T}$ in long exegesis - but what about the Old Heirmologion? The 3T, as was also the case with later editors, never transcribed it - or at the very least, no one touched upon it or spoke about it here in Greece, save M. Vassileiou and S. Karas. I pose now a simple question: would it be possible for a line such as this -

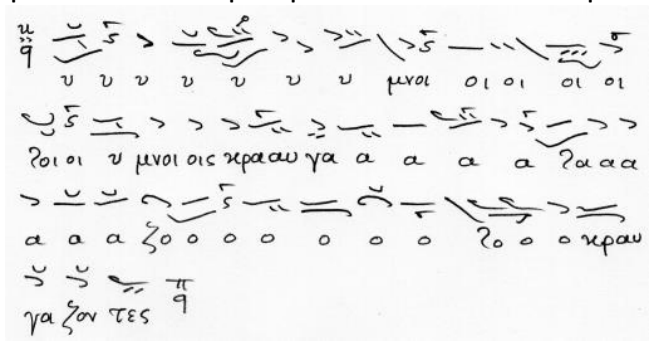

and such a line as this -

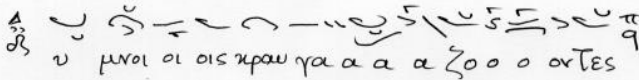

to be notated identically?

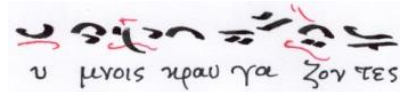

\footnotetext{
${ }^{15}$ Interestingly enough the finales of these sometime end on the note of $\mathrm{Ga}(\mathrm{F})$ or $\mathrm{Ne}(\mathrm{C})$ as well (if we consider a basis of Di for the fourth mode).

${ }^{16}$ This does not mean that the chromatic intervals were unknown in pre-conquest times. According to my research till now, it seems to have been introduced via the kalophonic chants, since the beginning of the $14^{\text {th }} \mathrm{c}$ or a little earlier. But the older chants of the Second modes found in Sticherarion, Heirmologion, Psaltikon, Asmatikon, as well as many papadic chants, were diatonic. The introduction of the chromatic intervals in kalophonic chants seems to have influenced the other chants, making them gradually chromatic.

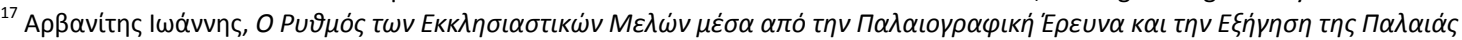

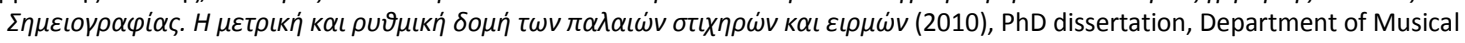
Studies, Ionian University, Kerkyra, 2010 (available at: https://www.didaktorika.gr/eadd/handle/10442/21885)
} 
The first is the exegesis given by the $3 \mathrm{~T}$ for this formula when found in the Sticherarion. The second is the exegesis of the formula when found in the Heirmologion, as it results from a comparison of the Heirmologion by Balasios to the Heirmologion by Petros Lampadarios. If we suppose that these exegeseis reflect the original way of rendering in sound the melodies of the medieval Sticherarion and Heirmologion, how would it be possible for such music lines, so different from one another, to be both "reduced" to the same initial sets of neumes? How was the choice of certain combinations of signs made, and not of some others? My own answer to this question is that the original interpretation was a short exegesis that became longer through stages of development.

\section{On long exegesis}

To take a broader view of the problem, however, there are elements that lead one to suspect the existence of long exegesis even in earlier periods. Perhaps not necessarily as long as that of the 3T, but

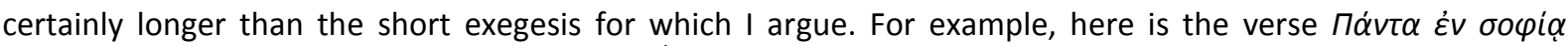

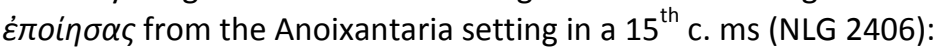

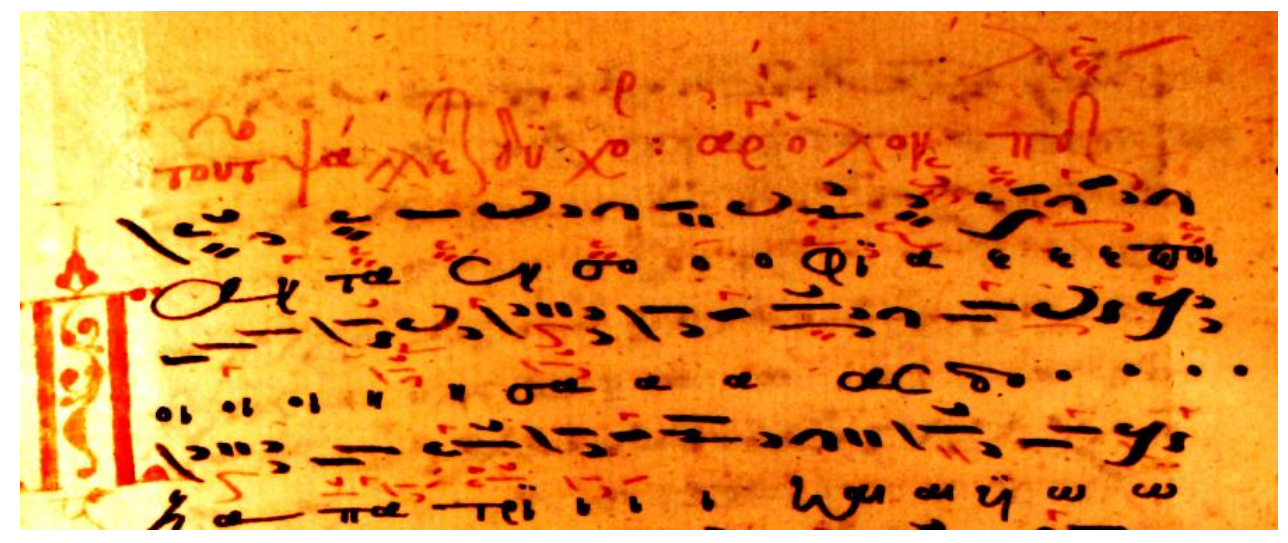

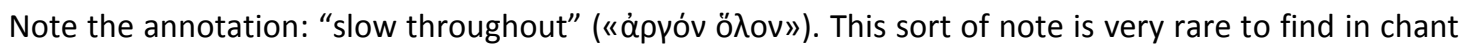
books, in even bulky papadic anthologies, and such comments of course do not present an open-and-shut case for long exegesis. In this instance, however, what seems probable to me is that such a rare instruction indicating one melos' slow tempo is the scribe's way to differentiate it from the other, faster and shorter, chants.

As an additional point - why does the scribe add "throughout"? Why not just indicate "slow"? Further analysis suggests other nuances; indeed, there could exist cases of chants performed in a slow manner only partially, i.e. at some points, in comparison with the standard, simpler, short reading of the notation. I have collected such cases in my own study of stichera, and to a lesser extent from heirmoi, but also from mele of the Papadike and the Psaltikon as well. Throughout the mss. I have studied, there are abundant examples demonstrating a selective doubling of durations at some points compared with the usual appearance of the theseis in other or the same ms.

The fact that the long exegesis certainly existed immediately before the $3 \mathrm{~T}$ is apparent from all the transcriptional attempts - not only by those known as exegetai (Balasios, Petros Lampadarios etc), but also by various others that have not been sufficiently referred to yet as exegetai, such as Antonios the Priest and Oeconomos at the beginning of $18^{\text {th }} \mathrm{c}$.

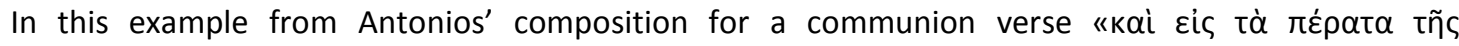

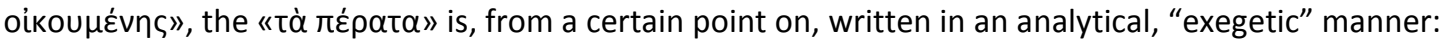




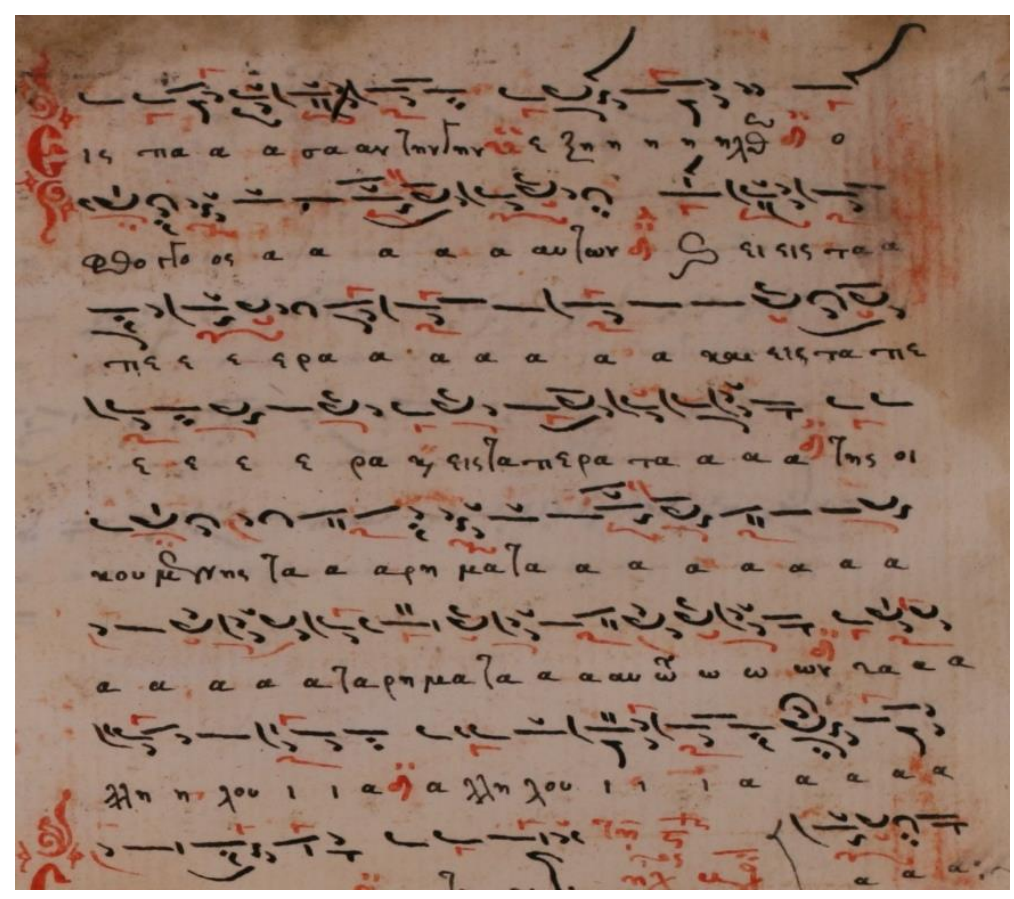

Despite a slightly different transcription from the $3 \mathrm{~T}$, it is clearly the same thesis. Regardless, this line could have been written in a more concise manner:

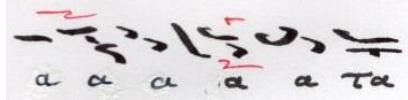

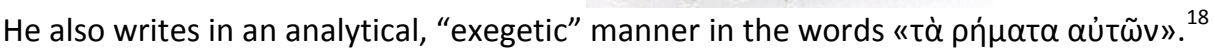

Therefore, it seems to me certain that there was a tradition of long exegesis at the time of the 3T, as well as much earlier, and that the $3 \mathrm{~T}$ did not transcribe as they did arbitrarily. I make this point because such opinions have been expressed, for example by Karas, who has written that long exegesis was an "occupation" ( $\left.\dot{v} v \alpha \sigma \chi \delta \lambda_{n} \mu \alpha\right)$ - his word to indicate the work of re-notating older melodies in such a way as to render them explicitly more melismatic that was undertaken by the exegetai of the 18th century. On the contrary, we now know that it was not solely an "occupation" of their invention, since the practice of (probably often shorter forms of) exegesis has been traced in manuscripts back to the $17^{\text {th }}$ century. That being said, over time there seems to have been a growing tendency to employ ever longer forms of exegesis for transcribing chant repertories of the distant past. Already fully characteristic of the work undertaken by the exegetai of the later eighteenth century, it became the default method of the 3T, who seem in most cases to have preferred the longest possible exegesis.

\section{Epilogue}

In conclusion, the centuries-long journey of the neumes appears to have started with a short and simple interpretation, and cantors gradually proceeded to multiply their durations and ornaments. This is the tradition that the $3 \mathrm{~T}$ received, and it is this transcriptional method, the slow or long exegesis, that they passed to us, in the NM notation. This exposition of mine on the short exegesis and the dispute over their work, is meant in no way to doubt their achievements in their own time; it is simply my answer to the question whether what they passed to us accurately represents the original soundscape of the old chants. The soundscape that reached the $3 \mathrm{~T}$ is one passed to them through the continuous process of received tradition, through procedures that naturally leave trails of enrichment and change; and as a matter of fact, tradition always has the right to do so. This is what they received and this is what they passed to us, during a period when, if they had not intervened somehow, things would probably be much harder for us chanters today - not only in our study of the theory of chant, but for us even to chant at all. For this, I certainly agree that they were rightly characterised as "benefactors of the Nation"; and so, "Rest in peace!"

\footnotetext{
${ }^{18}$ There is a scribal error at this point in this ms; some phonetic signs have been omitted. There can be specific reasons for Antonios' decision to write in an "exegetic" manner, but this subject cannot be elaborated here.
} 